\title{
Respiratory Symptoms Among Domestic Waste Collectors
}

\author{
Evsel Atık Toplayıcılarında Solunum Belirtileri
}

\author{
Loganathan Salvaraji $\odot$, Mohammad Saffree Jeffree $\odot$, Richard Avoi $\odot$, Hazelina Mohd Akhir $\odot$, \\ Syed Sharizman Syed Abdul Rahim $\odot$, Khamisah Awang Lukman $\odot$
}

Ethics Committee Approval: This study was approved by the Universiti Malaysia Sabah, Jawatankuasa Etika Penyelidikan Perubatan, Clinical Studies Ethics Committee, 27 December 2019, JKEtika 3/19(27).

Conflict of interest: The authors declare that they have no conflict of interest.

Funding: This study is fully funded under Universiti Malaysia Sabah, Malaysia (Code: SDNO0672019.

Informed Consent: Informed consent was taken from the participants enrolled in this study.
Cite as: Salvaraji L, Jeffree MS, Avoi R, Akhir HM, Rahim SSSA, Lukman KA. Respiratory symptoms among domestic waste collectors. Medeni Med J. 2020;35:304-9.

\begin{abstract}
Objective: Increasing amount of waste concurrently increases the risk of exposure to hazardous materials among waste collectors. Vigorous exertion in the field intensifies the abundance of contaminated inspirable droplets. If left undetected and untreated, it may provoke significant pernicious health effects and redundant burdens to employees and employers. The purpose of this study is to determine the prevalence of respiratory symptoms and their associated factors among domestic waste collectors.

Method: A cross-sectional study was conducted in Kota Kinabalu, Sabah between January and April 2020. Data were collected using a validated questionnaire which encompasses details about sociodemographic, health status, environment, and employment characteristics.

Results: A total of 290 waste collectors with a mean age of $40( \pm 9)$ years old were participated in the study. Most of them were from Kadazan-Dusun-Murut ethnic origin with educational background till secondary school. The average monthly income of the workers was USD 298.45 $( \pm 171.9)$ per month, and they had been in service for $11( \pm 9.04)$ years. Respiratory symptoms were seen in $21 \%$ of the workers. The identified significant risk factors were determined as underlying chronic diseases $(O R=2.34 ; 95 \% \mathrm{Cl}=1.054,5.219)$ and contact with pets $(O R=1.87$; 95\% $\mathrm{Cl}=1.004,3.288$ ).

Conclusion: Respiratory symptoms are prevalent amidst domestic waste collectors and related to their health and field activities.
\end{abstract}

Keywords: Waste collectors, respiratory systems, occupational epidemiology

Öz

Amaç: Artan miktarda atık, atık toplayıcılar arasında tehlikeli maddelere maruz kalma riskini de aynı zamanda artırır. Sahada aşırı çalışma, kontamine damlacıkların solunma sıklığını artırır. Tespit edilmezse ve tedavi olunmazsa, önemli zararlı sağlık sorunlarına, çalışanlar ve işverenler üzerinde yüklere neden olabilir. Bu çalıșmanın amacı, evsel atık toplayıcıları arasında solunum semptomlarının yaygınlığını ve ilişkili etkenleri belirlemektir.

Yöntem: Ocak-Nisan 2020 döneminde Kota Kinabalu, Sabah'da kesitsel bir çalıșma gerçekleștirilmiştir. Veriler, sosyodemografik değişkenler, sağlık durumu, çevre ve istihdam özellikleri ile ilgili ayrıntıları içeren geçerliği sağlanmıs bir anket kullanılarak toplanmıștır.

Bulgular: Ortalama yaşı 40 ( \pm 9 ) olan toplam 290 atık toplayıcı araştırmaya katılmıştır. Çoğu ancak ortaokula kadar eğitimli olan, Kadazan-Dusun-Murut etnik kökenli kişilerdir. İş̧ilerin aylık ortalama geliri 298,45 ABD doları $( \pm 171,9)$ olup, $11( \pm 9,04)$ yıldır hizmet vermektedirler. Solunum semptomlarının yaygınlı̆̆ı \%21 çıkmıștır. Araștırmada önemli risk faktörleri, altta yatan kronik hastalığı olma $(O R=2.34$; \%95 Cl=1.054, 5.219) ve evcil hayvanlarla temas (OR=1.87; $\% 95 \mathrm{Cl}=1.004$, 3.288) olarak belirlenmiștir.

Sonuç: Solunum semptomları evsel atık toplayıcılar arasında yaygındır ve bunlar kişilerin sağlık durumları ve sahadaki etkinlikleri ile ilişkilidir.

Anahtar kelimeler: Atık toplayıcılar, solunum sistemleri, mesleki epidemiyoloji
Received: 19 November 2020

Accepted: 8 December 2020

Online First: 25 December 2020

Corresponding Author: M.S. Jeffree

ORCID: 0000-0002-0373-4451

Universiti Malaysia Sabah,

Faculty of Medicine and Health

Sciences, Department of Community and Family Medicine, Sabah, Malaysia

saffree@ums.edu.my

\section{Salvaraji}

ORCID: 0000-0003-1160-5243

R. Avoi

ORCID: 0000-0002-1957-0965

H.M. Akhir

ORCID: 0000-0002-4932-436X

S.S. Syed Abdul Rahim

ORCID: 0000-0002-9090-2563

Universiti Malaysia Sabah,

Faculty of Medicine and Health

Sciences, Department of Community and Family Medicine, Sabah, Malaysia

K.A. Lukman

ORCID: 0000-0003-4840-2925

Universiti Malaysia Sabah, Center for Occupational

Safety and Health, Sabah, Malaysia 


\section{INTRODUCTION}

Waste management is a vigorous outdoor occupation that involves a plethora of activities such as collection, transportation, and processing of domestic waste. This raises the concern of the health impact of workers in contact with hazardous materials. Apart from direct contact with waste, workers also have a great risk of inhaling bioaerosols that release from decomposing organic waste or unfortunately present on the surface of the object ${ }^{1,2}$. The virus can survive long enough till self-inoculation in the environment, though its survival depends on the physical and chemical properties, such as temperature and humidity of the external conditions. The mode of transmission varies, and it possibly transfers from hand to surface and back again ${ }^{3}$. It is known that the prevalence of respiratory insufficiency was protrusile among waste collectors compared to indoor workers ${ }^{4}$. Twenty-eight percent of the waste-pickers experience respiratory symptoms which demonstrates a $13 \%$ increase in the risk of developing respiratory illness ${ }^{5}$. In fact, the amount of waste is estimated to surge with an increasing number of the population each year. In Beijing, 100.000 waste collectors processed four million tons of trash and further helped the recycling process of reusable items $^{6}$. The average amount of waste produced in Malaysia had doubled in $2003^{7}$. It is predicted that by the year 2020, the quantity of waste will surplus from 23.000 to 31.000 tons per day ${ }^{8}$. Subsequently, the risk of exposure to contaminated droplets during waste collection significantly raised to cause health problems on the workers.

On the other hand, it is necessary to take into consideration the vigorous activities during waste collection. Physiologically, waste collectors exert musculoskeletal work and physical force by continuously picking, carrying, and lifting the waste. These activities require extensive respiratory support through frequent inhalation to increase the flow of air into the lungs. Thus, there is a high possibility of environmental contamination with bioaerosols that may enter the lung and occupy a large volume. Once in contact with alveoli, bioaerosols further provoke and cause inflammation in lung tissues ${ }^{9}$. Several other factors may influence the incidence of respiratory illness especially working outdoors ${ }^{10,11}$. Hence, the purpose of this study is to determine the prevalence of respiratory symptoms and their associated factors among domestic waste collectors.

\section{MATERIALS and METHODS}

A cross-sectional study design was implemented among domestic waste collectors either working on a full-time or daily basis, between January and April 2020. The Municipal Council is responsible for coordinating waste collection within 351 square kilometres area consisting of sub-districts and towns. There are 317 male workers assigned as waste collectors, and they are divided into 58 groups. Each group consists of 5 to 6 waste collectors. Each team is assigned to a compactor lorry according to their working hours. Prior to moving to the designated location, all members gather at the main site operational office. Waste collectors give a report to the supervisor and prepare themselves before heading to the location. Then, teams disperse to the zones under coordination and order of the supervisor. In the field, they perform work tasks including picking up, carrying, and lifting waste, manipulating compactor lorry, unloading waste at the disposal site, and cleaning compactor lorry. The questionnaire was modified from local studies. Face validity was checked among 30 town cleaners who shared the same education characteristic of the study sample, followed by content validity review by experts in Public Health Medicine. Test-retest reliability analysis was also done in the same group. The questionnaire consists of four sections including sociodemographic, health status, environmental conditions, and employment characteristics.

The data were analysed using IBM Statistical Package for Social Sciences (SPSS) version 26. 
Obtained data were recoded into categorical set for chi-square and Fisher's Exact Test. A p-value of $<0.05$ was considered significant at $95 \%$ confidence interval. Then, variables with $p$-values less than 0.2 were selected for multivariate logistic regression analysis to identify the risk factors for respiratory symptoms. The backward and forward stepwise approach was applied during analysis. Further, the fitness of the model was tested for multicollinearity, interaction, Hosmer-Lemeshow goodness of fit test, and receiver operator characteristic (ROC) curve. Significant data were identified by $p$-value less than 0.05 with adjusted odds ratio and within 95\% confidence interval.

Study approval was obtained from the Medical Research Ethics Committee, and formal permission was acquired from the municipal council. There is no conflict of interest in this study. All registered waste collectors were selected as the study sample. Individual consents were taken prior to data collection.

\section{RESULTS}

Out of 317, 290 waste collectors participated in this study. The mean age was $40 \pm 9$ years (Table 1). Most of them are from Kadazan-Dusun-Murut ethnicity (47.2\%) and at the secondary school education level $(78.6 \%)$. The mean income was

Table 1. Respondent profile of waste collectors participated in the study $(\mathrm{N}=290)$.

\begin{tabular}{lll}
\hline Variables & No. (\%) & Mean (SD) \\
\hline Age & & $40(8.80)$ \\
Ethnicity & & \\
KDM & $137(47.2 \%)$ & - \\
Brunei & $63(21.7 \%)$ & - \\
Rungus & $44(15.2 \%)$ & - \\
Bajau & $33(11.4 \%)$ & - \\
Others & $13(4.5 \%)$ & - \\
Education level & & \\
Without education & $5(1.7 \%)$ & - \\
Primary school & $44(15.2 \%)$ & - \\
Secondary school & $228(78.6 \%)$ & - \\
Others & $13(4.5 \%)$ & - \\
Monthly salary (USD) & - & $298.45(171.9)$ \\
Duration of service & & $11(9.04)$ \\
& & \\
\hline
\end{tabular}

Table 2. Associated factors with respiratory symptoms among waste collectors $(\mathbf{N}=\mathbf{2 9 0})$.

\begin{tabular}{|c|c|c|c|c|c|}
\hline \multirow[b]{2}{*}{ Variables } & \multicolumn{2}{|c|}{ Respiratory symptoms } & \multirow[b]{2}{*}{$X^{2}(d f)$} & \multirow[b]{2}{*}{ t-test (df) } & \multirow[b]{2}{*}{ p-value } \\
\hline & $\begin{array}{l}\text { Yes }(\mathbf{N}=60) \\
\text { No. }(\%)\end{array}$ & $\begin{array}{l}\text { No }(\mathbf{N}=230) \\
\text { No. }(\%)\end{array}$ & & & \\
\hline Age & $39.05(9.024)^{a}$ & $39.84(8.752)^{a}$ & - & $0.621(288)$ & 0.535 \\
\hline \multicolumn{6}{|l|}{ Education level } \\
\hline Without education or Primary school & $13(26.5 \%)$ & $36(73.5 \%)$ & $1.226(1)$ & - & 0.268 \\
\hline Secondary school and above & $47(19.5 \%)$ & $194(80.5 \%)$ & - & - & \\
\hline Income (USD) & $381.47(175.92)$ & $387.62(159.66)$ & & $0.260(288)$ & 0.795 \\
\hline \multicolumn{6}{|l|}{ Smoking } \\
\hline Yes & $26(21.8 \%)$ & $93(78.2 \%)$ & $0.165(1)$ & - & 0.684 \\
\hline No & $34(19.9 \%)$ & $137(80.1 \%)$ & - & - & - \\
\hline \multicolumn{6}{|l|}{ Expose to natural water } \\
\hline Yes & $5(45.5 \%)$ & $6(54.5 \%)$ & $0.054 b$ & - & - \\
\hline No & $55(19.7 \%)$ & $224(80.3 \%)$ & - & - & \\
\hline \multicolumn{6}{|l|}{ Underlying chronic disease } \\
\hline Yes & $12(35.3 \%)$ & $22(64.7 \%)$ & $5.006(1)$ & - & 0.025 \\
\hline No & $48(18.8 \%)$ & $208(81.3 \%)$ & - & - & - \\
\hline \multicolumn{6}{|l|}{ Contact with pets } \\
\hline Yes & $35(27.3 \%)$ & $93(72.7 \%)$ & $6.183(1)$ & - & 0.013 \\
\hline No & $25(15.4 \%)$ & $137(84.6 \%)$ & - & - & - \\
\hline $\begin{array}{l}\text { Duration of service } \\
\text { Job task category }\end{array}$ & $10.97(9.130)^{a}$ & $11.06(9.03)^{a}$ & - & $0.068(288)$ & 0.945 \\
\hline Non-driver & $43(19.3 \%)$ & $180(80.7 \%)$ & $1.165(1)$ & - & 0.280 \\
\hline Driver & $17(25.4 \%)$ & $50(74.6 \%)$ & - & - & \\
\hline
\end{tabular}

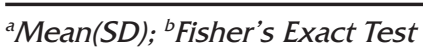


Table 3. Risk factors for respiratory symptoms among waste collectors $(\mathbf{N}=\mathbf{2 9 0})$.

\begin{tabular}{lllllll}
\hline & & & & & \multicolumn{2}{c}{ 95\% CI for Exp (B) } \\
\cline { 5 - 7 } Variable & B & S.E & Sig & Exp (B) & Lower & Upper \\
\hline Underlying Chronic Disease & 0.852 & 0.408 & 0.037 & 2.345 & 1.054 & 5.219 \\
Contact with pets & 0.597 & 0.303 & 0.049 & 1.817 & 1.004 & 3.288 \\
Constant & -2.048 & 0.252 & 0.000 & 0.129 & & \\
\hline
\end{tabular}

USD $298.45 \pm 171.9$ per month. They had been working for an average of $11 \pm 9.04$ years. Overall, $21 \%$ of waste collectors had experienced and complained of respiratory symptoms. Most of the symptoms were cough $(88.3 \%)$, sore throat $(75 \%)$, and flu (60\%). Waste collectors with underlying chronic diseases such as diabetes, hypertension, hyperlipidaemia, and cancer had experienced respiratory symptoms ( $p$-value $=0.025$ ) (Table 2 ). Waste collectors who have direct contact with pets ( $p$-value $=0.049$ ) at home also have a risk for respiratory symptoms. Overall, there is approximately two times risk of developing respiratory symptoms among waste collectors with underlying chronic diseases (OR=2.345; 95\% $\mathrm{Cl}=1.054$, 5.219) and contact with a pet (OR=1.817; $95 \%$ $\mathrm{Cl}=1.004,3.288$ ) (Table 3 ). In this study, there is no association between respiratory symptoms with age, education level, income, smoking, exposure to natural water, duration of employment, and job category.

\section{DISCUSSION}

The prevalence of respiratory symptoms is comparatively less than the study conducted in Klang Valley $(56.8 \%)^{12}$. Workers who develop respiratory symptoms appear to be older than our study. They started working at a later mean age of 31 years, but workers in our study began working at a younger mean age. In addition, absenteeism rates were significant predictors in the study; and they obviously reveal that a longer duration of exposure steps up the possibility of experiencing respiratory manifestations. However, the cough remained the most common symptom informed by the workers in both studies.
Another study affirms a slightly higher prevalence than our findings and shows a significant relationship between respiratory symptoms and the duration of employment ${ }^{13}$. The majority of workers were 48 years old on average, which is far-flung older than workers in our study. The workers likewise engaged in waste collecting activities for more than 20 years. Thus, the workers had been frequently exposed to contaminated droplets that possibly reflect on the higher manifestation of respiratory symptoms than the workers in our study. Nevertheless, our findings are concurrent with Djoharnis et al.'s study ${ }^{14}$ in which they reported $20 \%$ prevalence rate of respiratory symptoms among waste collectors. Their subjects' characteristic findings were roughly matching our mean age of 39 years and duration in service of 11 years ${ }^{14}$. In addition, that study explores further using spirometry and details that only $12.6 \%$ of their subjects had abnormal results.

When precisely assessing the respiratory risk factors for the waste collectors, our study affirms those with underlying chronic diseases and contact with pets were at higher risk of respiratory symptoms than others. Chronic diseases are noticed to alter biochemical mediators in the human body and further pare the competency of the immune system against numerous agents ${ }^{15}$. Hence, our study notes that the risk of developing respiratory symptoms doubled among waste collectors with chronic diseases. A cohort study highlighted individuals who received treatment for chronic diseases have ample risk for respiratory irritation. In addition, the study also explained other relevant factors such as obesity and being overweight associated with respiratory symptoms ${ }^{16}$. 
In comparison to our study, a reckoning of workers in the waste management industry was unable to affirm any association with chronic diseases. Although an akin prevalence rate of respiratory symptoms was demonstrated in our study, the exposure period in the field differs in that more than half of workers linked to other jobs and appointed by contract ${ }^{17}$. Another review highlighted approximately $60 \%$ of the workers categorized as having chronic diseases yet reported an imperceptibly lower prevalence rate of respiratory symptoms than our study. Probably extensive anomalous anthropometric measures among the workers might have led to musculoskeletal disorders becoming the major problem in this particular working environment rather than respiratory symptoms ${ }^{18}$.

Waste collectors are most likely to be in contact with animals such as rats, cats, dogs, and insects during waste collection activities. A limited number of studies were conducted to evaluate the association between respiratory symptoms and direct contact with animals. The investigation of an outbreak detailed that a worker in a rat-breeding facility possibly contaminated with transmission of the virus from rodents to humans and mild respiratory symptoms were experienced ${ }^{19}$. Likewise, a local survey reported that the workers developed respiratory symptoms just after a few minutes of close contact with animals, yet sneezing and stuffed noses were prevailing like in our study ${ }^{20}$. Although the average duration of employment was shorter than our study, they worked extensively up to 8 to 12 hours per day, and only half of them were in compliance with using personal protective equipment.

Unfortunately, contemporary research on the respiratory virus seroprevalence related to high-risk occupations in close contact with pets report findings in divergence to our study. The investigators posited that occupational exposure to pets entailed low transmission risks and this is apparently very common in the community. Results of this study were presumably influenced by the variation of their participants that certainly possess different frequencies and durations of exposure in their working environments, meanwhile our study targeted only domestic waste collectors ${ }^{21}$. Concurrently, another study was unable to find any association with worker-related symptoms with pets. The duration of service and the mean age were comparably below than our study that perhaps generated shorter duration of exposure to contaminated droplets that results in disparity between findings ${ }^{22}$.

\section{CONCLUSION}

In conclusion, there is a significant risk of developing respiratory symptoms due to the exposure to hazardous materials in waste which may lead to deliberate respiratory conditions among waste collectors. Those with comorbid chronic diseases and contact with animals further extend the possibility of experiencing respiratory symptoms. This high-risk occupation should be regularly monitored to hinder detrimental health effects and mortality. Our study contributes to the baseline data for occupational safety, may help health officers and policymakers to assess existing programs, strengthen control measures, subsequently, dwindle the incidence of respiratory manifestations among waste collectors.

\section{Acknowledgements:}

We expressed our utmost gratitude to the lecturers of the Department of Community and Family Medicine, Faculty of Medicine and Health Sciences, University Malaysia Sabah, and City Hall Committee for their support. Our heartfelt appreciation to family members and friends.

\section{REFERENCES}

1. Heldal KK, Halstensen AS, Thorn J, Eduard W, Halstensen TS. Airway inflammation in waste handlers exposed to bioaerosols assessed by induced sputum. Eur Respir J. 2003;21:641-5. [CrossRef]

2. Tschopp A, Bernard A, Thommen AM, et al. Exposure to bioaerosols, respiratory health and lung-specific proteins: 
a prospective study in garbage and wastewater workers. Occup Environ Med. 2011;68:856-9. [CrossRef]

3. Brady MT, Evans J, Cuartas J. Survival and disinfection of parainfluenza viruses on environmental surfaces. Am J Infect Control. 1990;18:18-23. [CrossRef]

4. Vimercati L, Baldassarre A, Gatti MF, et al. Respiratory Health in Waste Collection and Disposal Workers. Int J Environ Res Public Health. 2016;13:631. [CrossRef]

5. Chokhandre P, Singh S, Kashyap GC. Prevalence, predictors and economic burden of morbidities among wastepickers of Mumbai, India: a cross-sectional study. J Occup Med Toxicol. 2017;12:30. [CrossRef]

6. ZhouxiangZ. Sortwaste to ease garbagecollectors'burden. Updated at 2018. Available from http://www.chinadaily. com.cn/a/201812/08/WS5c0b23dea310eff30328fd88. html

7. Kathirvale S, Muhd Yunus MN, Sopian K, Samsuddin AH. Energy potential from municipal solid waste in Malaysia. Renew Energy. 2004;29:559-67. [CrossRef]

8. Manaf LA, Samah MA, Zukki NI. Municipal solid waste management in Malaysia: practices and challenges. Waste Manag. 2009;29:2902-6. [CrossRef]

9. Ray MR, Roychoudhury S, Mukherjee G, Roy S, Lahiri T. Respiratory and general health impairments of workers employed in a municipal solid waste disposal at an open landfill site in Delhi. Int J Hyg Environ Health. 2005;208:255-62. [CrossRef]

10. Matheson MC, Benke G, Raven J, et al. Biological dust exposure in the workplace is a risk factor for chronic obstructive pulmonary disease. Thorax. 2005;60:645-51. [CrossRef]

11. Wouters IM, Hilhorst SK, Kleppe P, et al. Upper airway inflammation and respiratory symptoms in domestic waste collectors. Occup Environ Med. 2002;59(2):10612. [CrossRef]

12. Zaleha M,Vikneswaran S, Diana M, Intan M, Humadevi S. Zaleha V, Diana I, Humadevi. The Prevalence Of Respiratory Symptoms Among Workers In A Domestic Waste Collection Center In Klang Valley, Malaysia. Int J Public Health Clin Sci. 2018;5:145-54.

13. Schantora AL, Casjens S, Deckert A, et al. Prevalence of
Work-Related Rhino-Conjunctivitis and Respiratory Symptoms Among Domestic Waste Collectors. In: Pokorski M, editor. Environment Exposure to Pollutants. Springer International Publishing. 2014. P:53-61. [CrossRef]

14. Djoharnis J, Shafei MN, Musa KI, Abdullah MR, Ibrahim MI. Respiratory Symptoms and Lung Functions among Domestic Waste Collectors: An Experience in a Developing Country like Malaysia. Int J Collab Res Intern Med Public Health. 2012;4:1775-84.

15. Bagatini MD, Cardoso AM, Dos Santos AA, Carvalho FB. Immune System and Chronic Diseases. J Immunol Res. 2017;2017:4284327. [CrossRef]

16. Guerrisi C, Ecollan M, Souty C, et al. Factors associated with influenza-like-illness: a crowdsourced cohort study from 2012/13 to 2017/18. BMC Public Health. 2019;19:879. [CrossRef]

17. Ewis AA, Mohamed ES, Rahma MA, Hifnawy TM, Arafa AE. Occupational Health-Related Morbidities Among Street Sweepers And Waste Collectors At Beni-Suef, Egypt. Egypt J Occup Med. 2013;37:79-94. [CrossRef]

18. Cruvinel VRN, Marques CP, Cardoso V, et al. Health conditions and occupational risks in a novel group: waste pickers in the largest open garbage dump in Latin America. BMC Public Health. 2019;19:581. [CrossRef]

19. Kerins JL, Koske SE, Kazmierczak J, et al. Outbreak of Seoul Virus Among Rats and Rat Owners - United States and Canada, 2017. MMWR Morb Mortal Wkly Rep. 2018;67:131-4. [CrossRef]

20. Zainal Abidin E, Mahmud Z, Jasni AS. Occupational Exposures To Bioaerosol And Its Link With Respiratory Symptoms Among Workers In Companion Animal Clinics: A Cross-Sectional Study. Int J Public Health Clin Sci. 2017;4:22-40.

21. Duggan JM, Close R, McCann L, et al. A seroprevalence study to determine the frequency of hantavirus infection in people exposed to wild and pet fancy rats in England. Epidemiol Infect. 2017;145:2458-65. [CrossRef]

22. Yilmaz I, Oner Erkekol F, Secil D, Misirligil Z, Mungan D. Cat and dog sensitization in pet shop workers. Occup Med (Lond). 2013;63:563-7. [CrossRef] 